\title{
PEMAHAMAN DAN UNJUK KERJA HIGIENE-SANITASI SISWA DALAM PENGOLAHAN DAN PENYAJIAN MAKANAN DI SMKN 1 KUBU
}

\author{
Luh Masdarini \\ Jurusan PKK (Tata Boga), FTK, Undiksha
}

\begin{abstract}
ABSTRAK
Tujuan penelitian ini untuk mengungkap dan mendeskripsikan pemahaman dan unjuk kerja higiene-sanitasi siswa dalam pengolahan dan penyajian makanan di SMKN 1 Kubu. Penelitian ini menggunakan rancangan penelitian deskriptif kuantitatif dengan subjek penelitian siswa kelas $X$ di SMKN 1 Kubu yang berjumlah 89 orang. Instrumen penelitian yang digunakan adalah tes pengetahuan, angket, dan lembar observasi. Selanjutnya data dianalisis dengan teknik deskriptif dengan menggunakan formula persentase. Hasil penelitian ini menunjukkan bahwa: (1) pemahaman higiene-sanitasi siswa dalam pengolahan dan penyajian makanan di SMKN 1 Kubu adalah baik, dengan persentase 69,88\%; dan (2) Unjuk kerja higiene-sanitasi siswa dalam pengolahan dan penyajian makanan di SMKN 1 Kubu adalah sangat baik dengan persentase $81,91 \%$.
\end{abstract}

Kata kunci: pemahaman, unjuk kerja, prinsip-prinsip higiene-sanitasi, SMK, pengolahan dan penyajian makanan.

\begin{abstract}
This study aims at discovering and describing the gastronomy students' hygienesanitation understanding and performance in SMKn 1 Kubu. This research is a descriptive quantitative one with research subjects are the gastronomy students class $\mathrm{X}$ of SMKN $1 \mathrm{Kubu}$ with the total number of 89 students. The instruments used are skill test, questionnaire and observation sheet. Then, the data are analyzed descriptively by using percentage formula. The data analysis shows that: (1) the gastronomy students' understanding over the hygiene-sanitation in SMKN 1 Kubu is good, with the percentage of $69,88 \%$, (2) the gastronomy students' performance over the hygiene-sanitation in SMKN 1 Kubu is very good, with the percentage of 81,91
\end{abstract}

Keywords: Understanding, ygiene-sanitation principles, SMK, food processing and serving 


\section{PENDAHULUAN}

Sekolah Menengah Kejuruan (SMK) sebagai bentuk satuan pendidikan kejuruan sebagaimana ditegaskan dalam penjelasan Pasal 15 UU Sisdiknas No.20 Tahun 2003, merupakan pendidikan menengah yang mempersiapkan siswa terutama untuk bekerja dalam bidang tertentu. Bidang Keahlian Tata Boga merupakan salah satu bidang keahlian yang dikembangkan pada Sekolah Menengah Kejuruan di Indonesia. Dalam Kurikulum SMK tahun 2004 Bidang Keahlian Tata Boga termasuk dalam kelompok program produktif yang meliputi beberapa mata diklat (mata pelajaran), salah satunya adalah mata diklat (mata pelajaran) Higiene-Sanitasi.

Pesatnya perkembangan pembangunan industri makanan di Indonesia saat ini, ternyata tidak diikuti dengan peningkatan kemampuan tenaga kerja dalam menangani pekerjaan secara aman dan sehat. Permasalahan higiene-sanitasi yang buruk dalam dunia industri makanan di Indonesia merupakan salah satu bentuk kelemahan tenaga kerja dalam menangani pekerjaan, dan ternyata merupakan masalah yang sangat memprihatinkan serta menjadi penyebab utama terjadinya kasus keracunan makanan.

Hal ini sesuai dengan hasil penelitian Agustin T. (2005:20) yang menyatakan bahwa keracunan makanan bisa disebabkan oleh mikroba patogen ataupun bahan kimia berbahaya. Semua jenis keracunan makanan di Indonesia lebih dari $90 \%$ disebabkan oleh kontaminasi mikroba yang berasal dari peralatan, bahan makanan, tubuh manusia, air, tanah, dan udara. Sisanya kurang dari 10\% disebabkan oleh bahan kimia baik berasal dari alam ataupun bahan kontaminasi lingkungan seperti pepstisida dan logam berat. Hasil penelitian yang dilakukan oleh Djarismawati (2008:2) pada 3 rumah sakit di Jakarta diperoleh kesimpulan bahwa proses pengolahan makanan di 3 (tiga) rumah sakit (Rumah sakit fatmawati, Rumah Sakit Pasar Rebo, dan Rumah Sakit Persahabatan) belum memenuhi syarat higienesanitasi makanan. Pengetahuan penjamah sudah baik, namun tempat pengolahan belum memenuhi syarat dan kurangnya pengawasan serta pembinaan terhadap proses pengolahan makanan. 
Suedarmadji (2007:19) mengemukakan bahwa angka statistik tahun 2007 menunjukkan lebih dari $60 \%$ penyakit bawaan makanan atau foodborne disease disebabkan karena kurangnya pemahaman higiene-sanitasi penjamah (tenaga pengolah) makanan dalam pengolahan makanan. Berdasarkan hasil penelitian yang dilakukan Purnawijayanti (2007:15) dinyatakan bahwa 80-85\% keracunan makanan di Indonesia disebabkan oleh faktor manusia. Unsur-unsur yang menyebabkannya antara lain: (1) kurangnya pengetahuan para penjamah (tenaga pengolah); (2) kurangnya keterampilan tenaga pengolah; dan (3) motivasi kerja yang menurun.

Profesional merupakan sikap mental untuk secara sungguh-sungguh menghayati pekerjaan dan menguasai segala aspek di dalamnya, mengingat setiap pekerjaan seperti mengolah makanan memiliki banyak aspek. Diantara banyak aspek, higiene dan sanitasi merupakan aspek mutlak yang harus dikuasai karena berbagai alasan. Pertama, adanya sikap kritis konsumen yang makin meningkat; kedua, pada umumnya owner atau manajemen menuntut hal yang serupa pada tenaga pengolah; ketiga, tenaga pengolah membutuhkan tingkat kesehatan dan keselamatan kerja. Jadi jelas sudah bahwa pendidikan mengenai higiene-sanitasi menjadi hal yang begitu penting untuk ditanamkan pada pelaksana pengolah makanan.

Sehubungan dengan hal tersebut, fenomena atau kenyataan yang tampak ternyata kriteria beberapa profesionalisme di atas belum sepenuhnya diterapkan. Hal ini didukung oleh hasil survey pada beberapa SMK yang menunjukkan bahwa tingkat kesadaran serta disiplin para siswa SMK terhadap pelaksanaan higienesanitasi dalam proses pengolahan makanan masih minim. Hal ini terlihat dari prilaku siswa dalam proses pengolahan makanan, mulai dari tahap persiapan sampai penyajian belum sepenuhnya menerapkan prinsip higiene- sanitasi. Dalam tahap persiapan siswa sering tidak mencuci bahan makanan yang akan diolah, selain itu sering memakai peralatan-peralatan yang kurang bersih, tidak memakai seragam kerja terutama tutup kepala (cerpus), membiarkan sampah berserakan di atas meja kerja (tidak menyediakan alat untuk sampah), banyak siswa yang berkuku panjang dan memakai perhiasan seperti cincin. Jadi sikap positif siswa terhadap pekerjaan dan keinginan bekerja dengan hasil yang berkualitas masih kurang. Hal ini jelas 
sekali terlihat pada saat siswa melakukan pengolahan makanan di luar jam pelajaran, seperti misalnya pada saat siswa menerima pesanan makanan. Memang pada saat menerima pesanan guru pembina jarang yang bisa memandu secara maksimal karena kegiatannya di luar jam kerja yaitu sore bahkan malam hari. Padahal konsep higiene-sanitasi sudah diberikan sejak awal memasuki bangku sekolah.

Berdasarkan fenomena-fenomena di atas, maka dipandang perlu untuk mengungkap permasalahan ini dalam suatu penelitian.

\section{METODE PENELITIAN}

Penelitian ini merupakan penelitian deskriptif kuantitatif yang bertujuan untuk mengungkap dan mendeskripsikan pemahaman dan unjuk kerja higienesanitasi siswa dalam pengolahan dan penyajian makanan di SMKN 1 Kubu yang datanya berbentuk data interval. Subjek penelitian ini adalah siswa kelas X SMKN 1 Kubu yang berjumlah 89 orang. Instrumen penelitian yang digunakan adalah tes pengetahuan, angket, dan lembar observasi. Tes pengetahuan digunakan untuk mengukur variabel pemahaman higiene-sanitasi siswa dalam pengolahan dan penyajian makanan. Bentuk tes yang digunakan adalah soal tes tertulis pilihan ganda. Panduan atau lembar observasi unjuk kerja digunakan untuk mengukur variabel yang berkaitan dengan unjuk kerja higiene-sanitasi siswa dalam pengolahan dan penyajian makanan yang berbentuk Check-list. Selanjutnya data yang terkumpul dianalisis dengan teknik deskriptif dengan menggunakan formula persentase.

\section{HASIL DAN PEMBAHASAN}

Data yang diperoleh dalam penelitian ini meliputi data tentang pemahaman dan unjuk kerja siswa terkait dengan higiene-sanitasi dalam pengolahan dan penyajian makanan di SMKN 1 Kubu. Seluruh data dalam penelitian ini dikumpulkan dengan tes dan lembar observasi terhadap 89 responden yaitu siswa kelas X SMKN 1 Kubu. Dari sejumlah data tersebut setelah dilakukan verifikasi diperoleh kepastian bahwa seluruh data sejumlah 89 eksemplar siap untuk dianalisis.

Penyajian hasil penelitian dipilah menjadi: (1) pemahaman higiene-sanitasi siswa, dan (2) unjuk kerja higiene-sanitasi siswa dalam pengolahan dan penyajian 
makanan. Deskripsi hasil analisis deskriptif pemahaman dan unjuk kerja higienesanitasi siswa dalam pengolahan dan penyajian makanan di SMKN 1 Kubu disajikan dalam Tabel 1 berikut:

Tabel 1. Hasil Penelitian Higiene-Sanitasi Siswa dalam Pengolahan dan Penyajian Makanan di SMKN 1 Kubu

\begin{tabular}{|l|c|c|}
\hline \multicolumn{1}{|c|}{ Aspek } & Persentase (\%) & Kategori \\
\hline Pemahaman higiene-sanitasi & 69,88 & Baik \\
\hline Unjuk kerja higiene-sanitasi & 81,91 & Sangat baik \\
\hline
\end{tabular}

Deskripsi data pada Tabel 3.1 menunjukkan satu aspek termasuk dalam kategori baik yaitu pemahaman higiene-sanitasi dengan persentase $69,88 \%$, dan satu aspek lagi termasuk dalam kategori sangat baik yaitu unjuk kerja higiene-sanitasi dengan persentase $81,91 \%$. Deskripsi data secara rinci mengenai pemahaman dan unjuk kerja siswa SMKN 1 Kubu terkait dengan higiene-sanitasi dalam pengolahan dan penyajian makanan adalah sebagai berikut:

\subsection{Pemahaman Higiene-Sanitasi Siswa dalam Pengolahan dan Penyajian Makanan di SMK N 1 Kubu}

Pemahaman merupakan kemampuan seseorang untuk memahami sesuatu yang dapat dilihat dari daya serapnya terhadap materi yang dipelajari kemuadian mampu mengaplikasikan ke dalam bentuk lain. (Batam Institusional, 2001:20). Siswa dapat dikatakan paham terhadap sesuatu apabila siswa tersebut mampu memaknai konsep-konsep yang diperoleh dalam teori pembelajaran, dan mampu mengaplikasikan secara riil dalam suatu kegiatan. Pemahaman higiene-sanitasi siswa dalam pengolahan dan penyajian makanan yang dimaksud dalam penelitian ini meliputi: (1) konsep dasar higiene-sanitasi, (2) prinsip-prinsip higiene-sanitasi, (3) pengolahan makanan, (4) penyimpanan makanan matang, dan (5) penyajian makanan. Hasil analisis deskriptif data penelitian tentang pemahaman higienesanitasi siswa dalam pengolahan dan penyajian makanan di SMKN 1 Kubu, disajikan dalam Tabel 2 berikut. 
Tabel 2. Hasil Penelitian Pemahaman Higiene-Sanitasi Siswa di SMK Negeri 1 Kubu

\begin{tabular}{|l|c|l|}
\hline Aspek & Persentase (\%) & Kategori \\
\hline Konsep dasar higiene-sanitasi & 72,22 & Baik \\
\hline Prinsip-prinsip higiene-sanitasi & 76,15 & Sangat baik \\
\hline Pengolahan makanan & 60,84 & Baik \\
\hline Penyaimpanan makanan matang & 59,25 & Baik \\
\hline Penyajian makana $\mathrm{n}$ & 62,96 & Baik \\
\hline
\end{tabular}

Deskripsi data hasil penelitian pemahaman higiene-sanitasi di SMK Negeri 1 Kubu yang disajikan pada Tabel 2 menunjukkan empat aspek termasuk kategori baik, yaitu: konsep dasar higiene-sanitasi persentase 72,22\%, pengolahan makanan persentase $60,84 \%$, penyimpanan makanan matang persentase $59,25 \%$, dan penyajian makanan persentase $62,96 \%$. Sedangkan satu aspek termasuk kategori sangat baik yaitu: prinsip-prinsip higiene-sanitasi persentase $76,15 \%$. Hal ini berarti bahwa mayoritas siswa di SMKN 1 Kubu sudah memahami dengan baik aspekaspek higiene-sanitasi yang dimaksud dalam penelitian ini, yaitu mengenai konsep dasar higiene-sanitasi, prinsip-prinsip higiene-sanitasi, pengolahan makanan, penyimpanan makanan matang, dan penyajian makanan.

Berdasarkan hasil penelitian tersebut, dapat dijelaskan bahwa ditunjukkannya pemahaman siswa yang sangat baik tentang higiene-sanitasi tidak lepas dari peranan guru yang memiliki wawasan luas tentang higiene-sanitasi dan begitu proaktif dalam melaksanakan proses pembelajaran. Pengetahuan tentang higiene-sanitasi tidak hanya diulas dalam teori Mata Diklat Higiene-Sanitasi dan K3, namun juga disisipkan dalam pembelajaran Mata Diklat Produktif yang berkaitan dengan pengolahan dan penyajian makanan. Hal ini bertujuan untuk memotivasi dan menekankan pada siswa agar pengetahuan higiene-sanitasi yang ditransfer kepada siswa dapat diterima dengan mudah dan diaktualisasikan secara nyata dalam pembelajaran praktik pengolahan dan penyajian makanan yang menuntut adanya persyaratan higiene-sanitasi.

Dalam proses pembelajaran Higiene-Sanitasi dan K3 yang diberikan pada semester I, guru senantiasa mengajak siswa dalam dunia nyata seperti misalnya mengajak siswa langsung ke dapur pengolahan untuk melihat sarana dan prasarana 
dapur yang harus dijaga higiene-sanitasinya serta memberikan contoh penerapan higiene-sanitasi yang benar, untuk selanjutnya diikuti oleh siswa. Hal ini memerlukan adanya tenaga guru yang benar-benar memiliki pemahaman dan wawasan yang luas tentang higiene-sanitasi. Berdasarkan pengamatan peneliti sebagian besar tenaga guru yang mengajar di SMK Bidang Keahlian Tata Boga di Bali adalah tenaga guru yang sudah sering mengikuti pelatihan/ magang baik di tingkat nasional maupun internasional, selain itu beberapa guru khususnya pada SMK Pariwisata adalah praktisi hotel yang sudah paham dan terbiasa menerapkan higiene-sanitasi.

Temuan ini di dukung oleh pernyataan Direktorat penyehatan lingkungan (1995) yang menyatakan bahwa dalam proses pengolahan makanan, pemahaman penjamah tentang higiene-sanitasi mempengaruhi citra dan kualitas makanan. Penjamah harus memahami dengan baik prinsip-prinsip higiene sanitasi seperti prinsip higiene-sanitasi pribadi (penjamah), higiene-sanitasi bahan makanan, higiene-sanitasi peralatan, higiene-sanitasi ruang pengolahan, dan higiene-sanitasi pengolahan dan penyajian makanan.

\subsection{Unjuk Kerja Higiene-Sanitasi Siswa dalam Pengolahan dan Penyajian Makanan di SMK N 1 Kubu}

Caplin dalam Elida (2009:70) mengemukakan ”unjuk kerja adalah tingkah laku yang membuahkan suatu hasil, khususnya tingkah laku yang dapat mengubah lingkungan dengan cara-cara tertentu”. Soekamto (1985: 78) menyatakan bahwa unjuk kerja dalam hal ini disinonimkan dengan performance yakni cara melaksanakan suatu tugas dan hasilnya, hasil kegiatan. Berdasarkan kedua pandangan tersebut, maka dapat dianalisa bahwa unjuk kerja merupakan tingkah laku dan performance seseorang dalam melakukan suatu kegiatan yang membuahkan suatu hasil yang dapat mempengaruhi lingkungan sekitarnya .

Unjuk kerja higiene-sanitasi siswa dalam pengolahan dan penyajian makanan yang dimaksud dalam penelitian ini meliputi: (1) penerapan higienesanitasi penjamah makanan, (2) penerapan higiene-sanitasi bahan makanan, (3) penerapan higiene-sanitasi peralatan, (4) penerapan higiene-sanitasi ruang 
pengolahan, dan (5) penerapan higiene-sanitasi pengolahan dan penyajian makanan. Hasil analisis deskriptif data penelitian tentang unjuk kerja higiene-sanitasi siswa dalam pengolahan dan penyajian makanan di SMKN 1 Kubu, disajikan dalam Tabel 3 berikut

Tabel 3. Hasil Penelitian Unjuk Kerja Higiene-Sanitasi Siswa di SMK Negeri 1 Kubu

\begin{tabular}{|l|c|c|}
\hline \multicolumn{1}{|c|}{ Aspekl } & $\begin{array}{c}\text { Persentase } \\
(\mathbf{\%})\end{array}$ & Kategori \\
\hline $\begin{array}{l}\text { Penerapan higiene-sanitasi penjamah } \\
\text { makanan }\end{array}$ & 80,50 & Baik \\
\hline Penerapan higine-sanitasi bahan makanan & 95,83 & Sangat baik \\
\hline Penerapan higiene-sanitasi peralatan & 95,76 & Sangat baik \\
\hline Penerapan higiene-sanitasi ruang pengolahan & 86,11 & Sangat baik \\
\hline $\begin{array}{l}\text { Penerapan higiene-sanitasi pengolahan dan } \\
\text { penyajian makanan }\end{array}$ & 79,53 & Kurang \\
\hline
\end{tabular}

Deskripsi data hasil penelitian yang disajikan pada Tabel 3 menunjukkan tiga aspek termasuk dalam kategori sangat baik, yaitu: penerapan higiene-sanitasi bahan makanan persentase $(95,83 \%)$, penerapan higiene-sanitasi peralatan persentase $(95,76 \%)$ dan penerapan higiene-sanitasi ruang pengolahan persentase $(86,11 \%)$. Dua aspek termasuk dalam kategori baik yaitu:penerapan higiene-sanitasi penjamah makanan persentase $(80,50 \%)$, dan penerapan higiene-sanitasi pengolahan dan penyajian makanan persentase $(79,53 \%)$.

Hasil analisis deskriptif data penelitian menunjukkan bahwa $81,91 \%$ unjuk kerja higiene-sanitasi siswa dalam pengolahan dan penyajian makanan di SMKN 1 Kubu adalah termasuk dalam sangat baik. Berdasarkan data tersebut, dapat dinyatakan bahwa mayoritas siswa di SMKN 1 Kubu sudah mampu menerapkan dengan sangat baik lima aspek unjuk kerja higiene-sanitasi yang dimaksud dalam penelitian ini yaitu: penerapan higiene-sanitasi penjamah makanan, penerapan higiene-sanitasi bahan makanan, penerapan higiene-sanitasi peralatan, penerapan higiene-sanitasi ruang pengolahan, dan penerapan higiene-sanitasi pengolahan dan penyajian makanan. Berdasarkan hasil penelitian tersebut dapat dijelaskan bahwa komitmen siswa untuk menunjukkan unjuk kerja higiene-sanitasi dalam pengolahan 
dan penyajian makanan begitu tinggi baik dalam hal penerapan higiene-sanitasi penjamah makanan seperti pemakaian pakaian kerja yang memenuhi standar higiene-sanitasi yaitu lengkap dengan topi, masker, dan sarung tangan, penerapan higiene-sanitasi bahan makanan dengan memilih bahan makanan yang berkualitas baik serta mencuci bahan pada air yang mengalir, penerapan higiene-sanitasi peralatan dengan menggunakan peralatan yang bersih, dan tidak cacat, serta membersihkan peralatan sesuai dengan karakteristiknya, penerapan higiene-sanitasi ruang pengolahan dengan menyapu dan mengepel area ruang pengolahan dengan desinfektan setelah selesai proses pengolahan makanan, serta penerapan higienesanitasi pengolahan dan penyajian makanan dengan melakukan teknik pengolahan yang memenuhi standar higiene-sanitasi serta melakukan penyajian makanan dengan alat bantu sendok sehingga tidak kontak langsung dengan tangan.

Hasil temuan ini didukung oleh penelitian sejenis yang dilakukan oleh Siti Nurhidyati (2008) terhadap tempat wisata bahari Lamongan menunjukkan bahwa perilaku hidup bersih dan sehat para pengungjung di wisata bahari Lamongan sudah cukup baik. Perilaku hidup bersih, dan sehat karyawan penjamah makanan (food handling) juga sudah cukup baik.

\section{PENUTUP}

Berdasarkan hasil penelitian dan pembahasan dapat disimpulkan bahwa: pemahaman higiene-sanitasi siswa dalam pengolahan dan penyajian makanan di SMKN 1 Kubu adalah baik, dan Unjuk Kerja Higiene-Sanitasi Siswa dalam pengolahan dan penyajian makanan di SMKN 1 Kubu adalah sangat baik. Mengacu pada kesimpulan di atas, maka disarankan: (1) bagi Kepala SMKN 1 Kubu diharapkan tetap meningkatkan pengendalian higiene-sanitasi yang ada di laboratorium atau bengkel sekolahnya, melalui penyediaan fasilitas higiene-sanitasi khususnya kelengkapan pakaian kerja berupa sarung tangan dan masker sehingga dapat memenuhi kebutuhan yang berkaitan dengan peningkatan higiene-sanitasi dalam pelaksanaan pengolahan dan penyajian makanan, (2) bagi guru diharapkan tetap aktif mengikuti pelatihan-pelatihan yang berkaitan dengan peningkatan higiene-sanitasi untuk ditransfer pada siswa, dan tetap berupaya mengembangkan 
pola pikir siswa khususnya mengenai higiene-sanitasi melalui penyisipan pendidikan karakter dalam proses pembelajaran, baik pembelajaran teori maupun praktik dalam upaya menciptakan lulusan yang professional, kompetitif, dan siap kerja, (3) bagi siswa diharapkan tetap mempertahankan dan mengembangkan pemahaman dan unjuk kerja higiene-sanitasi yang telah dicapai sehingga menjadi suatu kebutuhan dan terbiasa melaksanakan higiene-sanitasi yang optimal sebagai bekal terjun ke dunia industri

\section{DAFTAR PUSTAKA}

Agustina, T. 2005. Pentingnya Higiene Penjamah Makanan Tradisional. Semarang: Prosiding Seminar Nasional Membangun Citra Pangan Tradisional

Batam Institusional Depelopment Project, 2001. Konsep Pemahaman Pembelajaran.

Djarismawati. 2008. Pengetahuan dan Perilaku Penjamah Tentang Sanitasi Pengolahan Makanan Pada Instalasi Gizi Rumah Sakit Di Jakarta. Jurnal Sains \& Teknologi, (Online) Vol. XIV No. 2, (http://www.Jakarta.ac.id diakses 4 Oktober 2010).

Elida. 2009. Unit Produksi Pada Pendidikan Kejuruan Sebagai Implementasi Dari Proses Pembelajaran Yang Berorientasi Pada Produk Industri Yang Kreatif. Prosiding Seminar Nasional. Padang: Universitas Negeri Padang.

Nurhidyati. 2008. Kajian hygiene sanitasi tempat wisata di wisata bahari Lamongan dalam upaya pelaksanaan program pariwisata sehat tahun 2007. Jurnal Ilmiah Indonesia (Online) Vol. 3 No. 1 (http://jurnal.pdii.lipi.go.id/ index.php/Search.html) diakses 11 Oktober 2010.

Soedarmagji, S. 2007. Resiko Bahaya Dalam Keamanan Pangan Dan Faktor Penyebabnya. Jakarta: WKNPG V, LIPPI.

Soekamto, S. 1985. Kamus Sosiologi. Jakarta: Bumi Aksara.

UU Sisdiknas No.20 Tahun 2003.

Purnawijayanti. 2007. Hygiene Penjamah Makanan Untuk Keamanan Pangan. Yogyakarta: Laporan Penelitian Lemlit Universitas Gajah Mada. 